\title{
Politik Identitas dalam Pilkada DKI Jakarta Tahun 2017: Perspektif Pemikiran Politik Nurcholish Madjid
}

\section{Political Identity in DKI Jakarta Election 2017: Perspective of Nurcholish Madjid Political Thinking}

\author{
Idzam Fautanu' ${ }^{1}$ Buhori $\mathbf{M}^{2}$, Heri Gunawan ${ }^{3}$ \\ 1,3Universitas Islam Negeri (UIN) Sunan Gunung Djati Bandung \\ Jl. A.H. Nasution No. 105 Kota Bandung 40614, Indonesia \\ 2Institut Agama Islam Cipasung Tasikmalaya \\ Jalan Muktamar NU XXIX No.1, Cipakat, Cipasung, Singaparna, Cipakat, Kec. \\ Singaparna, Tasikmalaya, Jawa Barat 46417 \\ *corresponding author E-mail: idzamfautanu@uinsgd.ac.id
}

Diterima: 4 April 2020; Direvisi: 22 Juli 2020; Disetujui: 27 Juli 2020

\begin{abstract}
ABSTRAK
Munculnya kasus penistaan agama, dan gerakan aksi damai 212 telah menjadi pembangkit semangat umat Islam untuk memilih pemimpin yang seagama disinyalir menjadi faktor utama penggerak terpilihnya Anies-Sandi sebagai Gubernur dan Wakil Gubernur DKI Jakarta dalam Pilkada tahun 2017. Fokus dan tujuan penelitian pada artikel ini adalah untuk melihat pemikiranpemikiran politik Nurcholish Madjid dalam bangkitnya politik identitas pada Pilkada DKI 2017. Penelitian ini menggunakan pendekatan kualitatif dengan metode deskriptif. Adapun teknik pengumpulan datanya menggunakan observasi, wawancara mendalam dan teknik dokumentasi. Hasil penelitian menunjukkan bahwa politik identitas masyarakat Muslim DKI Jakarta dilandasi agama dan pada prinsipnya adalah suatu keniscayaan dalam budaya politik. Sementara corak politik identitas masyarakat Muslim DKI Jakarta dalam bentuk ukhuwah Islamiyah dan lebih kepada faktor budaya dan keagamaan. Diwujudkan dalam bentuk keaktifan dalam rangka mensukseskan kampanye, menggerakan masyarakat Muslim sebagai politik identitas dan mendukung kemenangan pasangan Anies-Sandi dalam Pilkada DKI Jakarta 2017.
\end{abstract}

Kata Kunci: Politik Identitas, Pilkada, Pemikiran Politik Nurcholis Madjid

\section{ABSTRACT}

The emergence of religious blasphemy cases and the peaceful action movement 212 have become the spirit of Muslims to choose their religious leaders who are allegedly the main factors driving the election of Anies-Sandi as the Governor and Deputy Governor of DKI Jakarta in the 2017 elections. The focus and purpose of the research in this article are to see the political thoughts of Nurcholish Madjid in the rise of identity politics in the 2017 DKI elections. This study uses a 
qualitative approach with descriptive methods. The data collection techniques using observation, in-depth interviews and documentation techniques. The results of the study show that the identity politics of the Jakarta Muslim community is based on religion and in principle is a necessity in political culture. Meanwhile, the identity style of the Jakarta Muslim community's identity is in the form of ukhuwah Islamiyah and more on cultural and religious factors. It is manifested in the form of activeness in the framework of the success of the campaign, moving Muslim communities as identity politics and supporting the victory of the Anies-Sandi couple in the 2017 DKI Jakarta elections.

Keywords: Identity Politics, Local Election, Nurcholis Madjid Political Thinking

\section{PENDAHULUAN}

Kasus Pilkada DKI Jakarta tahun 2017 telah menjadi fenomena dan menjadi perhatian masyarakat, bukan hanya publik DKI Jakarta, tapi juga masyarakat Indonesia secara keseluruhan. Munculnya kasus penghinaan AlQuran Q.S. Al-Maidah [5]: 51 (Sari, 2016) oleh salah satu pasangan calon (Paslon) telah membangkitkan semangat keberagamaan umat Islam, hingga memunculkan aksi damai 212 untuk datang berunjuk rasa di Jakarta, menjadi bagian yang sangat fenomenal. Aksi damai 212 di Jakarta merupakan wujud kuatnya hubungan antara agama (Islam) dengan politik (Negara) sebagai bentuk gejala politik identitas begitu kuat mewarnai dalam Pilkada DKI Jakarta tahun 2017 (Pradipta, Hidayah, Haya, Ervani, \& Kristanto, 2018).

Politik identitas tidak sama dengan "identitas politik." Karena identitas politik cenderung pada identitas yang dimiliki oleh seseorang atau kelompok orang yang berbeda dengan yang lain. Sedangkan "politik identitas" merupakan upaya yang dilakukan terhadap kepemilikan identitas untuk membangun sebuah perbedaan ("kami" dan "bukan kami") yang biasanya atas dasar ras, etnik, budaya ataupun bahkan agama teretantu (Andriyani, 2019). Politik identitas dapat diartikan sebagai rangkaian pemahaman, sikap dan tindakan (gerakan) politik yang didasarkan pada emosi, konsep, karakteristik atau kategorisasi yang berbeda dari kelompok atau masyarakat lain (Alfaqi, 2015).

Politik identitas masyarakat Muslim saat ini menjadi topik yang cukup 
aktual dalam kajian ilmu sosial-politik dan agama. Betapa tidak, fenomena politik identitas yang terjadi dalam masyarakat Muslim ini merupakan fenomena menarik dalam kehidupan sosial-politik dan keberagamaan, sehingga politik identitas menjadi masalah atau topik yang cukup 'seksi' untuk dikaji dan diteliti lebih lanjut.

Menurut Yoga Sukmana (2019), politik identitas sebenarnya bukanlah suatu masalah. Sebab ditinjau dari aspek kebudayaan, semua orang memerlukan identitas. Terkadang politik identitas akan menjadi masalah ketika "dimanipulasi" dan "dieksploitasi" sedemikian rupa secara berlebihan untuk kepentingan politik yang sempit, sehingga menjadi masalah. Padahal bila kembali melihat sejarah, masyarakat Indonesia adalah masyarakat yang majemuk atau multikultural. Hal ini, kata dia terjadi karena Indonesia adalah bangsa bahari. Indonesia sebagai bangsa bahari, komunitas yang tumbuh dan berkembang di setiap wilayah/bandar pasti memiliki ciri multikultural. Hubungan kultural antara satu suku dengan suku lainnya juga terjalin kuat. Oleh karena itu, satu identitas memiliki keterkaitan dengan identitas lainnya (Aswin, 2013).

Lebih lanjut, Pengurus Besar NU, Robikin Emhas, menilai politik identitas sama sekali bukanlah suatu hal yang negatif, akan tetapi bila dimunculkan secara berlebihan dan perbuatan isu suku, agama, ras, dan antargolongan (SARA) yang kuat, maka politik identitas bisa berbahaya, yang akan berdampak pada keharmonisan masyarakat. Mimbar-mimbar keagamaan akan menjadi panggung politik untuk kemudian mengkafirkan kelompok agama lain yang berbeda dalam pilihan politik. Bahkan yang seiman sekalipun bisa dikafirkan hanya semata-mata berbeda pilihan politiknya (Sukmana, 2019).

Kasus politik identitas yang terjadi di DKI tahun 2017 ini bukan berarti untuk mempertegas gagasan akan adanya pemisahan antara agama dari negara. Sebab agama Islam tidak mengenal dikotomi antara politik dengan agama. Dalam sejarah kerajaan di Indonesia misalnya, hubungan negara 
dengan agama ini erat sekali. Agama menghayati hidup kenegaraan seperti yang diperlihatkan oleh kerajaan Sriwijaya, Majapahit dan kerajaan-kerajaan Islam (seperti kerajaan Samudra Pasai, Malaka, Mataram, Aceh, Demak, dan lain sebagainya). Tahun 1920-an terjadi polemik di Indonesia tentang soal hubungan negara dengan agama, antara Ir. Soekarno dengan Haji Agus Salim, dan antara Soekarno dengan Mohammad Natsir pada tahun 1930-an. Menurut Deliar Noer, polemik ini ditengarai oleh perkembangan yang terjadi di dunia Barat, soal pemisahan antara gereja dari negara. Bagi negara Indonesia yang mayoritas beragama Islam, tidak relevan kalau adanya pemisahan antara agama dengan negara (Akbarudin, 2017).

Walau demikian, sikap tasamuh (toleransi) serta inklusif terhadap sesama dalam kehidupan soaial-politik /bermuamalah tetap diperlukan karena Allah telah berfirman:

"Wahai manusia sesungguhnya kami menciptakan kamu dari seorang laki-laki dan seorang perempuan dan menjadikan kamu berbangsa-bangsa dan bersuku-suku supaya kamu saling mengenal. Sesungguhnya orang yang paling mulia di antara kamu di sisi Allah ialah orang yang paling bertakwa di antara kamu. Sesungguhnnya Allah Maha Mengetahui lagi Maha Mengenal." (Q.S. Al-Hujurat []:13).

Sikap dan perilaku inklusif ini tentunya dalam seluruh aspek kehidupan, baik dalam masalah perbedaan ideologi, termasuk sikap politik. Dalam tradisi Islam tidak ada dikotomi antara politik dan bukan politik, karena politik itu merupakan keniscayaan dalam kehidupan. Orang yang menghindari politik serta beranggapan bahwa politik telah selesai maka kata Deliar Noer itu merupakan pemikiran khayali (utopian) saja. Politik tidak dapat dihindarkan selama manusia masih hidup bersama dan memerlukan hidup bersama, apalagi dalam kehidupan modern seperti kehidupan kini. Yang menjadi soal ialah isinya, cara bermain di dalamnya dan tujuan yang dikejar dalam berpolitik itu (Noer, 1983).

Nurcholish Madjid yang akrab disapa Cak Nur, berpendapat, setelah pembangunan bangsa (nation building) di masa presiden Soekarno, disusul 
pembangunan ekonomi di masa Presiden Soeharto tahap selanjutnya, mengharuskan adanya usaha yang lebih bersungguh dalam pembangunan sosial-politik, berbentuk pendemokrasian lebih lanjut kehidupan bernegara kita. Karena tahap itu jauh lebih rumit dan kompleks daripada tahap-tahap sebelumnya, maka tentu memerlukan partisipasi sebanyak mungkin warga negara. Masing-masing kita akan dituntut sumbangannya, berapapun ukuran sumbangan itu, ibarat biarpun sekedar berupa sekeping batu merah bagi bangunan istana demokrasi yang dicita-citakan. Salah satu bentuk pembangunan yang paling berharga adalah pengembangan sikap-sikap serba inklusif, pluralis, dan terbuka (Sugiyar, 2018).

Cak Nur sebagai cendekiawan Muslim telah memberikan sumbangan yang begitu besar dalam membangun kesadaran bangsa di bidang sosialpendidikan, kebudayaan, serta agama. Goenawan Muhammad misalnya pernah menulis tetang pemikiran dan sikap politik Cak Nur (Ulfa, 2013).

"Apa arti kemenangan Islam, “Cak Nur bertanya dan memberi jawabannya sendiri: "Kemenangan Islam tidak sama dengan kemenangan umat Islam, apalagi pribadi-pribadi. Kemenangan Islam adalah kemenangan sebuah ide, sebuah cita-cita terserah siapa orangnya, yang melaksanakan ide itu. Kemenangan Islam harus merupakan kebahagiaan bagi setiap orang, malah setiap makhluk. Kemenangan Islam tidak boleh diwujudkan dalam bentuk mengancam golongan lain."

Berdasarkan sikap ini nampak, tidak ada peleburan "yang lain menjadi sama". Cak Nur tetap berpandangan ada kehadiran yang terakhir, ada asalusul, ada dasar yang satu bagi segala 'arsy yang plural itu. Namun "yang lain” tidak dijinakkan. Pada dasarnya ini adalah satu sikap etis yang dalam -suatu sikap yang mempersoalkan, bahkan menggugat ego dan keleluasaannya terhadap "yang lain". Cak Nur tentu saja tetap berada dalam tradisi humaniesnya juga menekankan kembali peran manusia sebagai khalifah di atas bumi. Tetapi ia mencatat satu hal: kedo'ifan manusia. Pandangan ini tercermin juga pada sikap Cak Nur dalam politik, dan menjelaskan kenapa ia bersuara dengan sungguh-sungguh perkara demokrasi. "Perfeksionisme dan demokrasi adalah dua hal yang tidak pernah bertemu,". Perfeksionisme 
mengimplikasikan pandangan yang serba mutlak, demokrasi menuntut adanya pandangan kenisbian sampai batas yang cukup jauh".

Perhatian Cak Nur dalam bidang politik (kenegaraan) tercermin melalui surat-surat politik beliau dengan Muhammad Roem. Artikel Muhammad Roem yang dimuat di Panji Masyarakat Nomor 386 berjudul “Tidak Ada Negara Islam". Tulisan Roem ini rupanya menggelisahkan Cak Nur yang sedang belajar filsafat Islam di Chicago. Cak Nur pun menulis surat kepada Roem. Dari sinilah koresponden dua generasi cendekiawan Islam berawal, dan melihat kembali sejarah Islam lampau sebagai hikmah Islam di masa kini dan akan datang. Surat-surat itupun kemudian dibukukan sebagai sebuah dokumen politik (Madjid \& Roem, 2007).

Beberapa penelitian terdahulu seperti penelitian oleh Haboddin (2012) yang mengambil tema menguatnya identitas politik di ranah lokal, di mana menghasilkan bahwa politik identitas sangat penting dalam proses negosiasi dengan entitas local. Lalu, Hakiki (2011) yang melihat suatu fenomena identitas politik melalui perspektif aliran kebatinan menghasilkan bahwa setiap konflik pada identitas politik memiliki sebuah solusi yang telah diwariskan dari leluhur sebelumnya sehingga dapat diselesaikan dengan baik. Dan, penelitian yang dilakukan Sari (Sari, 2016) yang bertema kebangkitan politik identitas Islam pada arena pemilihan Gubernur Jakarta yang menghasilkan kebangkitan politik identitas Islam terjadi melalui upaya pembangunan citra diri dan menegakkan harga diri sebagai Muslim yang terhina sehingga sesama Muslim harus memilih mereka yang seagama dan seiman. Pada artikel ini penulis melihat politik identitas dari perspektif yang berbeda dari beberapa penelitian tersebut dimana pada artikel ini penulis mengambil dari perspektif seorang tokoh yaitu Nurcholish Madjid dengan menganalisis secara mendalam pemikiran beliau akan politik identitas yang sedang hangat di masyarakat.

Berdasarkan pada beberapa penjelasan di atas, maka diperlukan kajian lebih lanjut, melalui penelitian yang lebih dalam tentang politik identitas 
masyarakat Muslim DKI Jakarta yang kemudian dianalisis dengan menggunakan pemikiran politik Cak Nur. Berdasarkan latar belakang masalah tersebut, muncul pertanyaan bagaimana landasan politik identitas, corak politik dan perilaku masyarakat Muslim DKI Jakarta dalam Pilkada 2017." Maka penelitian ini pada dasarnya untuk mengetahui, (1) landasan pemikiran politik identitas Masyarakat Muslim pada Pilkada DKI Jakarta Tahun 2017 dalam analisis pemikiran politik Nurcholish Madjid; (2) Corak pemikiran politik identitas masyarakat Muslim pada Pilkada DKI Jakarta Tahun 2017 dalam analisis pemikiran politik Nurcholish Madjid; (3) Bentuk-bentuk perilaku politik identitas masyarakat Muslim pada pilkada DKI Jakarta Tahun 2017 dalam analisis pemikiran politik Nurcholish Madjid.

\section{METODE PENELITIAN}

Penelitian ini menggunakan pendekatan kualitatif. Penelitian kualitatif (Kaelan, 2010) lebih menekankan pada segi kualitas secara alamiah terkait konsep, nilai serta ciri-ciri yang melekat pada objek penelitian. Peneliti menggunakan pendekatan kualitatif karena beberapa pertimbangan, Pertama, pertimbangan teoritis. Penelitian ini menggunakan teori perilaku sosial dengan fokus kajiannya dimaksudkan untuk memotret perilaku politik masyarakat Muslim DKI Jakarta pada Pilkada 2017. Kedua, pertimbangan praktis, karena penelitian kualitatif ini secara fundamental bergantung pada pengamatan manusia dalam lingkungannya sendiri dan berhubungan dengan orang-orang tersebut baik dalam bahasanya maupun peristilahannya. Dalam tataran operasionalnya, pendekatan kualitatif ini juga dapat memudahkan peneliti dalam melakukan penelitian. Selama proses penelitian, peneliti berhubungan langsung dengan masyarakat Muslim DKI Jakarta. Ketiga, penelitian ini menekankan pada usaha menjawab pertanyaan penelitian. Pendekatan kualitatif dipandang cocok dengan fokus penelitian, karena apa yang dilakukan peneliti bukan dalam rangka menguji hipotesis untuk memperoleh signifikan/relevansi atau tidaknya perbedaan atau hubungan variabel. Tetapi pendekatan kualitatif dimaksudkan untuk menjawab 
pertanyaan, menemukan makna-makna dari fenomena, mengkategorisasi dari data atau fenomena, serta mengejar makna-makna sampai kepada akar-akar masalah dalam fokus penelitian.

Adapun metode yang digunakan adalah metode deskriptif, hal ini dimaksudkan untuk menjelaskan fakta-fakta di lapangan secara faktual, kemudian disajikan secara sistematis, sehingga lebih mudah dipahami dan disimpulkan. Selain itu, karena metode deskriptif merupakan bagian dari karakteristik pendekatan kualitatif, dan dibutuhkan dalam penulisan laporan penelitian ini deskripsi data dalam bentuk kata-kata atau gambar. Metode ini juga memiliki relevansi dengan kasus yang diteliti tentang perilaku politik identitas dalam masyarakat Muslim DKI Jakarta menggambarkan karakteristik masyarakat atau suatu kelompok orang secara deskriptif, sistematis, dengan mengungkap fakta-fakta akurat mengenai latar belakang yang mempengaruhi terjadinya politik identitas masyarakat Muslim pada Pemilukada DKI Jakarta 2017. Sesuai dengan pendekatan penelitian yang digunakan, maka dalam penelitian ini adalah data kualitatif baik berupa katakata maupun bentuk lainya. Adapun teknik pengumpulan datanya melalui observasi (pengamatan), wawancara mendalam (depth interview) dan studi kepustakaan atau dokumentasi (Aslichati, 2014).

Analisis data menggunakan reduksi data, display data, dan mengambil kesimpulan dan verifikasi. Peneliti mencari makna data yang dikumpulkannya. Untuk itu ia mencari pola, tema, hubungan, persamaan, halhal yang sering timbul, dan sebagainya. Jadi data yang diperolehnya sejak semula berupaya mengambil kesimpulan. Analisis data dilakukan secara kontinyu dari awal sampai akhir penelitian. Demikianlah maka dalam penelitian kualitatif termasuk penelitian agama proses analisis berjalan dinamis selama waktu penelitian berlangsung (Kaelan, 2010).

\section{TEMUAN DAN PEMBAHASAN}

\section{Landasan Pemikiran Politik Identitas Masyarakat Muslim DKI Jakarta}

Terjadinya Politik identitas masyarakat Muslim dalam pilkada DKI 
Jakarta dipicu oleh adanya peristiwa penistaan agama (Islam) yang dilakukan oleh calon petahana yakni BTP di kepulauan seribu (Djuyandi \& Azmi, 2017). Kasus ini menjadi katalisator dalam mempersatukan dan sekaligus menjadi memotivasi umat Islam Jakarta maupun luar Jakarta untuk ikut terlibat dalam sebuah gerakan bela Al-Quran dan bela Islam. Peristiwa gerakan aksi damai 212 di Monas sebagai bagian dari gerakan politik identitas masyarakat Muslim DKI Jakarta. Walaupun jika dianalisis secara mendalam, peristiwa aksi damai 212 itu bukan hanya sekedar untuk masyarakat Muslim DKI Jakarta saja, namun juga bagi masyarakat Muslim lain yang ada di luar DKI Jakarta, bahkan termasuk masyarakat Muslim di negara yang lain. Gerakan aksi damai 212 ini bukan hanya sekedar fenomena sosial-keagaman, namun juga aksi ini menjadi sangat monumental, dan menyejarah terutama bagi umat Islam di Indonesia (Abdullah, 2018).

Perhatian pada aksi ini bukan hanya terjadi di tanah air, namun juga menjadi perhatian dunia. Apalagi negara-negara Islam. Hal ini bukan tanpa alasan, karena peristiwa aksi super damai 212 ini diduga sampai mencapai 7 juta orang, dan kasus tersebut menyangkut persoalan identitas agama Islam. Politik identitas sebetulnya dapat membangun kekuatan politik Islam, dan ukhuwah Islamiyah sebagai bagian dari proses politik identitas. Adanya ukhuwah Islamiyah, bagaimana identitas agama dan identitas kemanusiaan menyatu dalam ikatan keyakinan, iman atau kekuatan tauhid. Dengan adanya ukhuwah Islamiyah yang kuat, maka kekuatan politik Islam akan tercipta dan terbangun dengan sendirinya.

Dengan adanya politik identitas sebetulnya menjadi "modal" dan kekuatan yang luar biasa dalam memenangkan kekuatan politik (pasangan calon pemimpin tertentu), hal ini sudah terbukti dengan terpilihnya pasangan Anies-Sandi yang terpilih menjadi Gubernur dan Wakil Gubernur DKI Jakarta, karena ia bisa menjadi terpilih sebagai gubernur karena didukung dengan adanya kekuatan politik identitas yang terciptakan secara alamiyah atau diciptakan karena misalnya Islam politik maupun politik Islam. 
Memang dalam konsep agama Islam, antara Islam dan politik tidak dapat dipisahkan, ini bukan hanya menjadi doktrin dalam ajaran agama Islam, namun juga antara politik dengan agama (Islam) itu sudah menjadi kepentingan kehidupan sosial-keagamaan. Hal ini tidak hanya terjadi hari ini saja, tetapi sudah terjadi sejak zaman Rasulullah saw., dan para sahabatnya. Rasulullah selain menjadi Rasul, juga sebagai kepala Negara.

Begitu juga dengan para shahabat, selain menjadi penyebar agama, juga menjadi khalifah. Oleh karena itu, antara Islam dengan politik menjadi bagian yang tidak dapat dipisahkan. Ungkapan simbolik hubungan Islam dengan negara dari sebagaimana dikemukakan oleh K.H. A. Wahab Hasbullah: "Bila seseorang bisa memisahkan gula dari mAniesnya, ia akan bisa memisahkan Islam dari politik" (Hasbullah, 2017). Hal ini menandakan bahwa Islam dan politik, agama dan negara memang tidak dapat dipisahkan satu sama lainnya. Hal ini tentunya sangat berbeda dengan di negara-negara Barat, Amerika dan Eropa misalnya, yang mencoba memisahkan antara keduanya.

Jika dianalisis secara mendalam, politik identitas yang terjadi pada masyarakat Muslim DKI Jakarta pada kasus Pilkada DKI Jakarta tahun 2017 lebih pada konteks ideologis (Karmida, 2018). Hal ini dikarenakan masyarakat Muslim DKI Jakarta dalam menentukan pilihan politik menjadikan keyakinan pada agama Islam sebagai azas dan pijakan dalam sikap dan gerakan politik, mereka cenderung menolak pada pilihan calon pemimpin yang bukan dari agama Islam. "Karena saya Muslim, maka saya pilih Anies." Begitu yang dikemukakan oleh masyarakat DKI Jakarta. Atau adanya ungkapan "Asal Jangan Ahok" hal tersebut merupakan bentuk kesadaran warga DKI Jakarta yang beragama Islam terhadap pilihan politik untuk memilih pemimpinnya yang akan memimpin mereka selama lima tahun ke depan. Ha ini menurut Ali Syariati, Ideologi merupakan suatu kesadaran diri istimewa manusia yang membimbingnya untuk merelakan diri dalam berperang, berkorban dan berpasrah diri (Dewi, 2012).

Sekalipun di antara masyarakat Muslim DKI Jakarta seperti saudara 
Khalimi, menyebutkan bahwa politik identitas itu sebenarnya tidak terjadi pada pemilukada DKI Jakarta 2017, namun karena ada penistaan agama yang dilakukan oleh Ahok pada salah satu ayat, yakni pada Q.S. Al-Maidah ayat 51, sehingga itu menjadi penyebab dan pemicu terjadinya konflik antara Muslim dan non Muslim, dan akibatnya muncul gerakan keagamaan yakni aksi damai 212 yang dimotori oleh para tokoh agama, ulama, habaib, dan masyarakat Muslim di tanah air. Sehingga aksi damai ini menjadi momen yang tepat dan sekaligus pintu masuk bagi pasangan Anies-Sandi untuk memenangkan Pilgub DKI Jakarta tahun 2017. Momentum ini tentu penggerak utamanya adalah, para ulama, habaib, para politikus yang mampu memanfaatkan situasi dan peluang, serta adanya gerakan massa Islam yang merasa terpanggil untuk membela Al-Quran dan Islam, serta adanya fatwa ulama yang berkaitan dengan penistan yang di lakukan oleh Ahok di kepulauan Seribu.

Berdasarkan pada peristiwa di atas muncul isu adanya perbedaan agama dan etnis. Islam dan non-Islam, China dan bukan China, mayoritas dan minoritas, hingga sampai muncul gerakan politik yang mengusung tagline "Asal bukan Ahok" atau "Asal Jangan Ahok". Oleh karena itu, sebagian kalangan menganggap pada Pilkada DKI Jakarta tahun 2017 memang terjadi politik identitas yang cukup kental, kuat, mendasar dan berdampak pada kehidupan sosial politik keagamaan.

Selain apa yang dikemukakan di atas, politik identitas di masyarakat Muslim Jakarta menyeruak pada isu dalam bentuk mayoritas-minoritas. Sehingga konsep mayoritas dan minoritas menjadi bagian dari politik identitas pada masyarakat Muslim Jakarta. Hal ini bukan tanpa masalah karena selama ini jumlah penduduk Muslim Jakarta berada pada angka lebih dari $83 \%$, sedangkan yang lainnya beragama non Islam.

Berdasarkan pada fakta tersebut di atas bahwa politik identitas pada prinsipnya adalah netral, ia tidak selalu bermakna negatif atau selalu selalu positif. Karena politik identitas adalah keniscayaan dalam budaya politik. Tinggal bagaimana mengemas politik identitas menjadi lebih etis dan 
berperadaban.

Fenomena munculnya politik identitas di masyarakat Muslim DKI Jakarta ditengarai dan dipicu oleh adanya kasus penistaan agama yang dilakukan oleh Ahok di Kepulauan Seribu, yang mengutip surat Al-Maidah ayat 51. Dalam kehidupan manusia, agama memiliki peran penting sebagai standar moralitas tertinggi. Agama juga berperan dalam kehidupan publik sebagai identitas agama dan identitas politik (Andriyani, 2019).

Kemudian antara Islam dan politik dalam keyakinan masyarakat Muslim Jakarta sesuatu yang tidak dapat dipisahkan. Mengutip dalam pandangan Cak Nur, ajaran Islam yang universal itu karenanya hanya bisa ditangkap dalam bentuk nilai, sehingga ketika ia turun dan jatuh ke tangan manusia, ia menjadi bentuk-dalam pengertian-budaya. Dalam pengertian bentuk budaya itulah Islam bisa muncul dalam berbagai warna dan corak. Karenanya berdasarkan kenyataan-kenyataan serupa itu, Islam dikenal dalam sejarah sebagai sangat akomodatif terhadap budaya-budaya setempat dan yang ada di sekelilingnya. Statement yang sering diungkapkan Cak Nur dalam setiap tulisannya, menunjukkan bahwa Cak Nur memang berpegang kepada paham semacam itu: mempertahankan yang lama yang baik, dan mengambil yang baru yang lebih baik. Bagi Cak Nur modernisme tidak mesti tercerabut dari nilai, etika, moral, kemanusiaan, dan agama.

Tentang pemikiran dan sikap politik Cak Nur. "Apa arti kemenangan Islam, " Cak Nur bertanya dan memberi jawabannya sendiri: "Kemenangan Islam tidak sama dengan kemenangan umat Islam, apalagi pribadi-pribadi. Kemenangan Islam adalah kemenangan sebuah ide, sebuah cita-cita terserah siapa orangnya, yang melaksanakan ide itu (Alam, Rafiudin, \& Sonjaya, 2020). Kemenangan Islam harus merupakan kebahagiaan bagi setiap orang, malah setiap makhluk. Kemenangan Islam tidak boleh diwujudkan dalam bentuk mengancam golongan lain.

Sikap politik masyarakat Muslim Jakarta cukup objektif, terbuka, toleran, rasional dan berkemajuan. Adapun menguatnya politik identitas yang 
menyangkut etnis dan agama pada masyarakat Muslim Jakarta sebagai ekses dari kasus di Kepulauan Seribu. Sikap politik masyarakat Muslim Jakarta ini tidak dapat dilepaskan dari ideologi kebangsaannya yakni Pancasila. Dalam hal ini Pancasila disebutnya oleh Cak Nur sebagai Common Platform (kalimatun sawa') dari berbagai interest masyarakat Indonesia yang plural ini. Penggunaan istilah itu tidak sekedar secara arti bahwa kalimatun sawa' itu berarti persamaan melainkan juga secara kontekstual bahwa penggunaan itu dalam Al Qur'an menunjukan bahwa tidak saja secara teologis umat manusia harus memiliki dan berpegang kepada titik persamaan, melainkan juga secara sosial yang merupakan prinsip transaksi sekuler.

\section{Corak Politik Identitas Masyarakat Muslim DKI Jakarta}

Berdasarkan pada data-data yang ditemukan di lokasi penelitian, bahwa dapat ditarik suatu benang merah bahwa corak atau bentuk-bentuk politik identitas yang ditemukan dalam masyarakat Muslim dalam pilkada DKI Jakarta tahun 2017 adalah, (a) Politik identitas dalam bentuk ukhuwah Islamiyah, (b) konsep musyawarah sebagai implementasi demokrasi Pancasila, dan sekaligus sebagai politik identitas masyarakat Indonesia, (c) Politik identitas masyarakat Muslim DKI Jakarta lebih kepada faktor budaya dan keagamaan, (d) Religiusitas, (e) Sebagai gerakan Amar ma'ruf nahi mungkar, (f) Politik identitas masyarakat Muslim DKI Jakarta sangat objektif dan proporsional, (g) Konsep agama Islam yang mengusung misi rahmatan lil alamin, (h) Identitas agama Islam menjadi faktor munculnya politik identitas, (i) Politik identitas dalam bentuk mayoritas dan minoritas. Masing-masing dijelaskan berikut ini:

Pertama, Politik identitas dalam bentuk ukhuwah Islamiyah menjadi kunci kesatuan dan kekuatan politik Islam dan umat Islam. Dengan adanya aksi damai 212, bagaimana ukhuwah Islamiyah dapat terjalin dan terwujud dalam masyarakat Muslim. Ukhuwah Islamiyah, sekalipun umat Islam berbeda suku, golongan, etnik, organisasi, dan ras, bersatu padu dalam satu keyakinan Islam atau tauhidullah (keyakinan keesaan / keimanan kepada Allah). Bahwa 
hanya Allah Tuhan semesta alam, yang berhak disembah. Hal ini sebagaimana telah disinggung di atas bahwa kekuatan politik Islam itu terletak pada ukhuwah (Tanthowi, 2019). Kekuatan politik identitas dengan ukhuwah itu sangat erat sekali. Oleh karena itu politik identitas masyarakat Muslim Jakarta diantaranya dalam bentuk ukhuwah. Sebagaimana dalam pandangan Cak Nur, ukhuwah islamiyah adalah sebuah resep untuk mengatasi persoalan yang kini menimpa kaum Muslim seluruh dunia. Persaudaraan berdasarkan atas iman adalah sangat sentral, dan tentu tepat sekali jika diyakini sebagai obat mujarab bagi berbagai penyakit umat (Nurcholish, 1997). Sedangkan sikap tertutup merupakan musuh utama prinsip ukhuwah.

Kedua, konsep musyawarah. Sebagai wujud dari demokrasi Pancasila, dan sekaligus politik identitas seluruh masyarakat Indonesia. Demokrasi Pancasila ditandai dengan adanya musyawarah (Mufakat, 2012), sehingga musyawarah ini menjadi identitas yang khas bagi demokrasi Indonesia, yakni demokrasi Pancasila. Karena diyakini demokrasi itu pun memiliki kelemahan, sehingga untuk menutupi kelemahan demokrasi itu diantaranya melalui musyawarah, dan itulah esensi demokrasi Pancasila.

Menurut Cak Nur demokrasi merupakan cara bukan merupakan tujuan. Oleh karena itu, demokrasi harus dipandang sebagai cara untuk mencapai tujuan, dan bukan tujuan itu sendiri. Bagi Cak Nur demokrasi itu pada umumnya mengacu pada suatu proses dalam pencapaian suatu tujuan atau hasil, dan bukannya tujuan atau hasil itu sendiri, bagaimanapun positifnya. Karena itu faktor partisipasi adalah sangat penting, sehingga terjadi perluasan sense of belonging yang mendasari rasa keadilan umum (Madjid, 1997). Dalam Pancasila prinsip demokrasi itu terungkap dalam sila keempat, yang berbunyi "Kerakyatan yang dipimpin oleh hikmah kebijaksanaan dalam permusyawaratan perwakilan"

Sebagai landasan dalam berdemokrasi, Pancasila dapat dilihat terdiri dari sila-sila yang terdapat di dalamnya. Sila pertama diyakini sebagai sila dasar yang melandasi seluruh sila Pancasila. Sila kedua merupakan pancaran 
sila pertama. Sila ketiga sebagai wahana. Sila keempat sebagai cara, dan Sila kelima sebagai tujuan. Untuk memandang seluruh sila itu sebagai kesatuan yang utuh, tidak bisa dipisah-pisahkan antara sila yang satu dengan sila yang lainnya. Sama seperti cara dan tujuan pun tidak bisa dipisah-pisahkan satu dari yang lain (Madjid, 1997).

Ketiga, Politik identitas masyarakat Muslim Jakarta (Betawi) lebih kepada faktor budaya dan keagamaan. Faktor kebudayaan dan keagamaan masyarakat Jakarta menjadi landasan dalam menentukan sikap dan gerakan politik dalam pilkada DKI Jakarta 2017 (Haboddin, 2017). Karena masyarakat Betawi yang identik dengan agama Islam membentuk pola budaya yang berbeda dengan etnis, atau suku yang lain, dimana masyarakat Betawi memiliki sikap dan perilaku yang hampir mirip dengan filosofi Sunda yakni silih asah, silih asih, dan silih asuh. Sehingga bagi masyarakat Betawi, tidak biasa dengan budaya marah-marah, atau kasar. Namun yang mereka butuhkan adalah, kelembutan, kesantunan dan dialog yang persuasif. Selain itu masyarakat Betawi memiliki tradisi balas pantun dan tradisi yang lain. Selain itu masyarakat Muslim Jakarta begitu kuat dengan tradisi keislamannya. Sehingga kebudayaan dan keagamaan menjadi faktor pembentukkan politik identitas pada masyarakat Jakarta. Sama seperti yang dikemukakan bahwa agama memiliki peran penting sebagai standar moralitas tertinggi. Agama juga berperan dalam kehidupan publik sebagai identitas agama dan identitas politik (Andriyani, 2019). Ketika agama berbaur ke dalam aktivitas masyarakat, maka agama dengan sendirinya akan membentuk jaringan peradaban masyarakat berdasarkan unsur-unsur kreatif manusia yang direfleksikan melalui karya-karya intelektual (Suyanta, 2018), seperti ekonomi, pendidikan, teknologi, seni, politik dan lain-lain.

Keempat, Religiusitas sebagai bagian dari politik identitas pada masyarakat Muslim DKI Jakarta. Dalam pandangan Cak Nur Manusia memiliki naluri religiusitas -naluri untuk berkepercayaan. Naluri itu bersamaan dengan hasrat memperoleh kejelasan tentang hidup dan alam raya yang menjadi 
lingkungan hidup itu sendiri (Nurcholish, 1997). oleh karenanya religiusitas pada masyarakat Muslim Betawi dengan sendirinya membentuk pola budaya, sosial, politik dan keagamaan, yang menjadi ciri khas masyarakat Betawi. Seperti terungkap bahwa masyarakat Muslim Jakarta punya moto: "Bukan Orang jakarta Kalau Tidak Bisa Ngaji”. Atau dalam kontek Pilkada Jakarta muncul sentimen politik: "Asal Bukan Ahok" (bukan Muslim dan Cina), serta muncul sentimen keagamaan: "Yang mendukung selain umat Islam tidak boleh disholatkan di mushola tertentu".

Kelima, Gerakan amar ma'ruf nahi mungkar bagian daripada politik identitas di masyarakat DKI Jakarta. Berdakwah karena motivasi agama lebih kuat mempengaruhi dalam pandangan, ideologi, sikap dan tindakan sosialkeagamaan dan politik. Kekuatan Islam yang berani bicara "tidak" dalam melihat kemungkaran politik rasanya perlu dibuka seluas-luasnya, agar dakwah Islam tidak menjadi misionaris yang a-politis terhadap tantangan kemanusiaan dan dehumanisasi politik. "Islam nilai" seperti itu tentu akan mampu melakukan konsolidasi moralitas mengahadapi krisis intensitas politik; dan selanjutnya akan bisa diklaim oleh siapa saja yang merasa memiliki komitmen nilai yang sama, tanpa terhalang perbedaan agama atau kelompok.

Keenam, Politik identitas masyarakat Muslim DKI Jakarta begitu objektif dan proporsional, artinya masyarakat Muslim Jakarta ketika melihat adanya kebaikan pada Ahok misalnya, mereka menerima dan mengakui. Seperti masyarakat Muslim mengapresiasi, sepakat, dan menerima ketegasan Ahok dalam menjaga kebersihan di lingkungan Jakarta. Sikap adil, dan terbuka inilah yang mencerminkan dari sebuah masyarakat Islam Jakarta yang betulbetul komitmen pada nilai-nilai ajaran Islam, dan sebagai cerminan dari masyarakat yang religius.

Ketujuh, Politik identitas masyarakat Muslim Jakarta dalam bentuk konsep rahmatan lil alamin. Selama ini Anies Memimpin Jakarta dengan tanpa kekerasan namun dengan dialog dan pendekatan yang komunikatif, inilah 
yang menjadi rahmatan bagi Jakarta. Rahmatan lil alamin, bagi masyarakat Muslim Jakarta tidak dapat dilepaskan dari nilai-nilai Islam yang kuat dan mendasar seperti konsep Iman, Islam dan Ihsan, keadilan, dakwah, dan juga rahmatan lil alamin itu sendiri. Faktor nilai Islam sebagai rahmatan lil alamin lah yang membentuk cara pandang, sikap dan perilaku termasuk faktor yang membentuk politik identitas masyarakat Muslim Betawi. Baik sebagai seorang pemimpin, maupun yang dipimpin, individual atau komunal. Peran dan fungsi agama sebagai instrumen perekat etnisitas dan nasionalitas dalam kehidupan kenegaraan yang demokratis akan dapat terwujud kembali. Peranan dan fungsi agama pada tataran demikian sekaligus membuktikan pembumian makna dan misi agama Islam sebagai rahmatan lil alamin (Muhamad, 2017).

Kedelapan, Identitas agama menjadi faktor munculnya politik identitas, Islam dan bukan Islam, apa yang terjadi dalam masyarakat Muslim Jakarta ketika Pilkada, kebanyakan masyarakat Muslim Jakarta memilih Anies-Sandi Karena faktor adanya kesamaan agama, yakni Islam. "Karena saya Muslim, saya pilih Anies-Sandi. Antara Islam dan politik tidak dapat dipisahkan, ini bukan hanya menjadi doktrin dalam ajaran agama Islam, namun juga antara politik (negara) dengan agama (Islam) itu sudah menjadi kepentingan kehidupan sosial-keagamaan.

Kesembilan, Politik identitas dalam bentuk mayoritas dan minoritas dalam pilkada Jakarta sangat kental sekali. Aksi damai 212 membuktikan kekuatan mayoritas umat Islam. Jumlah masyarakat Muslim DKI Jakarta yang mencapai lebih dari $83 \%$, menjadi modal utama bagi kekuatan politik Islam dan umat Islam sehingga mengantarkan Anies-Sandi menjadi Gubernur dan Wakil Gubernur DKI Jakarta pada tahun 2017. Sekalipun begitu, pentingnya Islam yang inklusif dalam arti toleransi kepada umat lain memang ada gunanya. Dewasa ini rasanya kebutuhan adanya Islam sebagai bendera politik bersama dalam rangka memperjuangkan demokrasi dan keadilan sosial menjadi tuntutan yang mendesak. Oleh karenanya tidak semua politik identitas dengan perbedaan agama akan menjadi kunci kemenangan politik, 
dan selalu bernilai positif, namun justru terkadang ketika isu perbedaan agama begitu kuat dan menjadikan sentimen negatif bagi kelompok yang lain. Ini bisa menjadi malapetaka dan menimbulkan bahaya dan bencana yang besar dalam kehidupan sosial-agama yang demokratis dan berperadaban. Bagi umat Islam sendiri, politik Islam itu suatu keharusan, karena Nabi dan para sahabat pun menjadi pemimpin dan menjadi khalifah, dan sekarang pun sama, meskipun caranya yang mungkin berbeda. Dan yang paling penting adalah bagaimana menciptakan politik yang damai, demokratis, berkemajuan dan berperadaban.

\section{Bentuk Perilaku Politik Identitas Masyarakat Muslim DKI Jakarta}

Adapun bentuk perilaku politik identitas yang ditemukan dalam masyarakat Muslim pada pilkada DKI Jakarta dalam analisis pemikiran politik Cak Nur adalah sebagai berikut: Pertama, memiliki perasaan senang dan bahagia dengan adanya gerakan aksi damai 212 karena gerakan ini membuktikan yang mungkin selama ini konsep ukhuwah hanya sebatas dalam pikiran, hanya konsep, atau cita-cita. Namun aksi damai 212 menjadi bukti nyata adanya ukhuwah Islamiyah. Ketika peristiwa aksi damai 212, mereka ikut terlibat karena itu menyangkut identitas. Mereka pada mau datang ke Monas karena mereka Muslim (Wawancara, 2019a). Mereka juga melihat aksi damai 212 ini merupakan moment untuk Anies naik menjadi Gubernur Jakarta waktu itu (Wawancara, 2019b).

Kedua, melalui gerakan amar ma'ruf nahsi mungkar. Prinsip ini merupakan esensi dakwah Islam. Dakwah itu kewajiban setiap orang, dakwah tidak hanya dalam bidang sosial-agama, namun juga dakwah dalam politik. menurut Cak Nur, "Dorongan kepada perbuatan baik itu sudah merupakan 'bakat primordial' manusia, bersumber dari hati nurani yang dalam bahasa Arabnya, nûrânî, bersifat nûr atau terang karena adanya fitrah pada manusia (Madjid, 2019). Karena dakwah prinsipnya merupakan proses transformasi, internalisasi dan sekaligus transmisi nilai-nilai ajaran Islam, termasuk di dalamnya pesan dakwah politik Islam yang membangun dan berperadaban 
untuk mencapai kebahagiaan di dunia dan akhirat. Selain itu ketika melihat kemungkaran, jalanan kotor, atau melihat kemungkaran politik mereka merasa terganggu. makanya hal seperti itu mereka kritisi. Oleh karena itu bagi mereka dakwah dengan motivasi agama lebih kuat dan besar pengaruhnya dalam kehidupan.

Ketiga, membangun komitmen. Membangun negara adalah dengan membangun komitmen (tidak adanya perselingkuhan politik). karena rusaknya sebuah negara dan pemerintahan karena tanpa adanya komitmen antar satu sama lain, baik pemimpin dengan rakyat, atau antar penyelenggara negara, dan penyelenggara negara dengan-konstitusi, serta rakyat dengan konstitusi. Membangun komitmen bersama dalam menciptakan suatu negara yang maju dan demokratis begitu sangat penting. Dan yang paling dasar adalah membangun kesadaran hukum (Darkum), sosial (Darso), ekonomi (Darmi), politik (Dartik) dan agama (Darma). Menurut pendapat Cak Nur , "Dalam kenyataan historis, perjuangan memperoleh dan mempertahankan harkat dan martabat kemanusiaan merupakan ciri dominan manusia sebagai makhluk sosial (Madjid, 2019).

Keempat, mendahulukan moral dan menjaga etika politik. Ilmu politik itu adalah kesejahteraan masyarakat, dan hakikat berpolitik adalah pengabdian pada masyarakat. Politik bukan hanya alat kekuasaan, atau bentuk kekuasaan, apalagi selalu ingin menguasai dan ingin menjadi penguasa. Bukan juga alat untuk melakukan perselingkuhan dalam politik, namun dalam setiap proses politik harus clear dan clean. Dalam menciptakan proses politik harus ditopang dan menjunjung tinggi nilai, moral, norma (Hukum, Sosial, dan Agama). Dan bagaimana menciptakan proses politik yang maju, bermoral, beretika, atau berakhlak ul karimah. Paling tidak terdapat tiga standar etika politik; norma hukum, tata nilai kesusilaan, kebiasaan. Kemudian diantara kelemahan demokrasi adalah perselingkuhan politik. Cak Nur menjelaskan bahwa baik dan jahat dalam kehidupan nyata seorang manusia di dunia akhirnya didefinisikan sebagai kualitas sikap, tingkah laku dan perbuatannya 
(Madjid, 2019).

Kelima, menciptakan dan memiliki sikap yang terbuka terhadap perbedaan. toleransi, saling menghormati, dan menerima atas kepemimpinan sekalipun dari luar golongan dan kelompoknya. Namun mereka tetap berharap supaya mayoritas menjadi pemimpin, atau kekuatan politik. Karena negara kita menganut sistem demokrasi, sehingga keputusan dapat diterima dengan terbuka. Asal jangan sampai pihak minoritas melakukan hegemoni terhadap mayoritas. Kalau minoritas melakukan penekanan terhadap mayoritas maka yang akan terjadi adalah disharmoni, itu yang tidak diharapkan dalam kehidupan berbangsa dan bernegara. Di dalam sistem demokrasi ini siapapun bisa menjadi penguasa (pemimpin), yang penting asal jangan dominasi minoritas terhadap mayoritas, dan tidak melakukan "perselingkuhan politik". Kita ingin menciptakan iklim politik yang terbuka, santun dan damai untuk menciptakan kesejahteraan bersama. Demokrasi di Indonesia adalah demokrasi Pancasila, dan hakikatnya demokrasi itu adanya musyawarah.

Keenam, memberikan apresiasi pada kebaikan dan prestasi namun dengan tetap bersikap kritis pada penyimpangan. Perilaku politik identitas Masyarakat Muslim Jakarta selain memiliki sikap terbuka atas perbedaan dan juga menerima sistem negara demokrasi (suara terbanyak yang memimpin). bahkan mereka juga tetap memberikan apresiasi bagi siapapun sang pemimpin, termasuk pada Ahok yang (berbeda Etnis dan beda agama) ada nilai-nilai kebaikan dan prestasi. Namun sikap kritis umat Islam tetap membara ketika melihat, kekurangan, kezaliman, ketidakadilan, dan pengkhianatan terhadap amanah kekuasaan. Siapapun pemimpinya, masyarakat Muslim Jakarta tetap bersikap kritis tapi etis, semua itu dilakukan dalam rangka amar ma'ruf nahi mungkar, Memerintah pada kebaikan, dan mencegah pada kemungkaran, atau kerusakan.

Ketujuh, perilaku politik identitas Masyarakat Muslim Jakarta diwujudkan dalam bentuk keaktifan dalam rangka menyukseskan, berupa 
kampanye, menggerakan serta mendukung untuk kemenangan pasangan Anies-Sandi dalam pilkada DKI Jakarta. Mereka mendukung dalam pengajianpengajian. melakukan gerakan (mobilisasi) bagaimana memotivasi lingkungan mereka, dan mempengaruhi khususnya kepada keluarga. Karena diantara mereka adalah alumni gerakan 212, bagi mereka aksi 212 ini memiliki pengaruh yang sangat kuat dan mendalam bagi sebuah pergerakan, dan dalam menentukan sikap politik.

Kedelapan, perilaku politik identitas yang dilakukan masyarakat Muslim Jakarta, dalam rangka melakukan gerakan politik untuk mendukung pada Anies-Sandi selain mengkampanyekan mereka pada keluarga, dan lingkungan masyarakat. Mereka juga sampai mengorbankan dan menyumbangkan dana pribadi untuk keperluan dalam mendukung pasangan Anies-Sandi. Pengorbanan dan sumbangan dana ini tidak perintah dari siapapun, namun atas kerelaan mereka masing-masing, bagi mereka ada keyakinan: setiap kebaikan, akan kembali kepada pemiliknya.

Melihat tentang bentuk perilaku politik identitas masyarakat Muslim DKI Jakarta Secara teoritis dapat dihubungkan dengan pendapatnya An-Na'im, bahwa faktor yang menentukan semua pilihan-pilihan tersebut antara lain: 1). pertimbangan untung dan rugi, 2). Pertimbangan sikap-sikap kelompokkelompok lain, internal maupun eksternal, terhadap "negosiasi identitas", yang konstan. 3) keyakinan atas kemampuannya memperoleh apa yang dipilihnya.

Dalam pandangan Cak Nur perbedaan politik tidak perlu mengurangi kehangatan kesukuan dan famili. Cak Nur memberikan pendapat tentang kesukuan dan famili. Pertama, jelas bukan pilihan kita, melainkan takdir ilahi, bahwa kita dilahirkan dalam suku tertentu dan famili tertentu. Karena telah menjadi takdir Allah, maka kita harus ridha kepada-Nya, dan memandang apa yang terjadi itu sebagai kemungkinan yang terbaik untuk diri kita. Berkenaan dengan kesuakuan ini dalam Quran disebutkan bahwa adanya berbagai bangsa dan suku haruslah dipandang sebagai kesatuan-kesatuan identitas 
yang berbeda-beda, yang harus saling kenal-mengenal. Karena itu tidak ada salahnya dalam batas-batas tertentu memelihara dan memperhatikan faktor kesukuan itu dalam pergaulan kita.

Selain itu menurut Cak Nur, implikasi dan remifikasi Ketuhanan Yang Maha Esa dalam Pancasila di antaranya akan menghasilkan nilai sebagai berikut: perbedaan antara sesama manusia harus disadari sebagai ketentuan Tuhan, karena Dia tidak menghendaki terjadinya susunan masyarakat yang monolitik. Pluralitas yang sehat justru diperlukan sebagai kerangka adanya kompetisi kearah berbagai kebaikan, sehingga perbedaan yang sehat merupakan rahmat bagi manusia (Madjid, 1997).

Melihat kenyataan perubahan sosial dan politik dalam suatu masyarakat kalau perubahan sosial dengan krisis-krisis yang ditimbulkan itu tidak diantisipasi dengan baik kata Cak Nur, akan menciptakan lahan yang subur bagi gejala-gejala radikalisme, fanatisme, sektarianiesme, fundamentalisme, eksklusivisme dan lain-lain yang serba negatif. Antisipasi itu pada urutannya, terkait dengan corak, pola atau sikap kepemimpinan yang relevan dengan dinamika perubahan itu sendiri. Kepemimpinan politik yang diperlukan dalam masa-masa perubahan sosial yang besar seperti sekarang ini ialah yang didasarkan pada sikap-sikap berikut:

1. Pengertian secukupnya akan hakikat perubahan zaman sekarang ini dalam dimensi global atau mondialnya (yang meliputi seluruh dunia). Karena banyak sekali hal-hal yang terjadi di tanah Air merupakan kelanjutan atau mempunyai keterkaitan dengan apa yang terjadi di dunia secara keseluruhan. Nilai-nilai sosial politik pun hampir tidak ada yang lepas dari apa yang terjadi di dunia secara keseluruhan. Seperti masalah demokrasi, keadilan, pemerintahan yang bersih, HAM, korupsi.

2. Pengertian yang cukup lengkap tentang budaya bangsa sendiri, sehingga dapat menduga, atau mengetahui secara persis, titik singgung antara pola budaya nasional dengan pola budaya mondial. Dalam rangka perubahan sosial, bisa jadi menghasilkan pola kontak yang simbiosis, atau 
menimbulkan benturan yang menimbulkan krisis. Dari pengetahuan itu diharapkan muncul kemampuan membuat antisipasi terjadinya krisis tertentu akibat perubahan sosial yang cepat dan besar.

3. Akomodasi positif terhadap perubahan, karena perubahan itu sendiri adalah keniscayaan. Sikap ini dapat diwujudkan pada sang pemimpin melalui sikap-sikap terbuka, menghargai pendapat orang lain, bebas, berpikir positif, inklusivistik (bersemangat persatuan dan kesatuan), demokratis (Anwar \& El Fiah, 2018).

\section{SIMPULAN}

Berdasarkan hasil penelitian dan temuan-temuan, serta hasil analisis terhadap data-data yang ditemukan tentang politik identitas masyarakat Muslim dalam Pilkada DKI Jakarta dapat disimpulkan sebagai berikut: Pertama, bahwa berdasarkan fakta di atas bahwa landasan pemikiran politik identitas masyarakat Muslim pada Pilkada DKI Jakarta pada prinsipnya adalah suatu netral, ia tidak selalu bermakna negatif atau selalu selalu positif. Karena politik identitas adalah keniscayaan dalam budaya politik. Namun tergantung bagaimana mengemas politik identitas menjadi lebih etis dan berperadaban. Fenomena munculnya politik identitas di masyarakat Muslim DKI Jakarta ditengarai dan dipicu oleh adanya kasus penistaan agama yang dilakukan oleh Ahok di kepulauan seribu, yang mengutip surat Al-Maidah ayat 51.

Kedua, bahwa corak politik identitas masyarakat Muslim pada Pilkada DKI Jakarta meliputi beberapa hal sebagai berikut, (a) politik identitas dalam bentuk ukhuwah Islamiyah, (b) konsep musyawarah sebagai implementasi demokrasi Pancasila, dan sekaligus sebagai politik identitas masyarakat Indonesia, (c) politik identitas masyarakat Muslim Jakarta lebih kepada faktor budaya dan keagamaan, (d) religiusitas, (e) gerakan amar ma'ruf nahi mungkar, (f) politik identitas masyarakat Muslim DKI jakarta sangat objektif dan proporsional, (g) konsep rahmatan lil alamin, (h) Identitas agama Islam menjadi faktor munculnya politik identitas, (i) Politik identitas dalam bentuk mayoritas dan minoritas. 
Ketiga, bentuk perilaku politik identitas Masyarakat Muslim pada Pilkada DKI Jakarta dalam analisis pemikiran politik Nurcholish Madjid. (a) memiliki perasaan senang dan bahagia dengan adanya gerakan aksi damai 212 karena gerakan ini menjadi bukti nyata adanya ukhuwah Islamiyah. Ketika peristiwa aksi damai 212, mereka ikut terlibat karena itu menyangkut identitas. (b) melalui gerakan amar ma'ruf nahi mungkar. Prinsip ini merupakan esensi dakwah Islam. Dakwah itu kewajiban setiap orang, dakwah tidak hanya dalam bidang sosial-agama, namun juga dakwah dalam politik. (c) membangun komitmen. Dan yang paling dasar adalah membangun kesadaran hukum (Darkum), sosial (Darso), ekonomi (Darmi), politik (Dartik) dan agama (Darma). (d) Mendahulukan moral dan menjaga etika politik. (e) menciptakan dan memiliki sikap yang terbuka terhadap perbedaan, toleransi, saling menghormati, dan menerima atas kepemimpinan sekalipun dari luar golongan dan kelompoknya. (f) Memberikan apresiasi pada kebaikan dan prestasi namun dengan tetap bersikap kritis pada penyimpangan. (h) perilaku politik identitas Masyarakat Muslim Jakarta diwujudkan dalam bentuk keaktifan dalam rangka mensukseskan, berupa kampanye, menggerakan serta mendukung untuk kemenangan pasangan Anies-Sandi dalam Pilkada DKI Jakarta 2017. Dan, (i) Perilaku politik identitas yang dilakukan masyarakat Muslim Jakarta, dalam rangka melakukan gerakan politik untuk mendukung pada Anies-Sandi selain mengkampanyekan mereka pada keluarga, dan lingkungan masyarakat. Mereka juga sampai mengorbankan dan menyumbangkan dana pribadi untuk keperluan dalam mendukung pasangan Anies-Sandi.

\section{DAFTAR PUSTAKA}

Abdullah, A. (2018). Membaca Komunikasi Politik Gerakan Aksi Bela Islam 212: Antara Politik Identitas Dan Ijtihad Politik Alternatif. An-Nida', 41(2), 202-212.

Akbarudin, A. M. (2017). Pemikiran Sm Kartosoewirjo Tentang Negara Republik Indonesia. In Right: Jurnal Agama Dan Hak Azazi Manusia, 2(2). 
Alam, A. S., Rafiudin, R., \& Sonjaya, A. (2020). Comparison Of Nurcholis Madjid And A. Hasyim Muzadi's Thoughts On Renewal In Indonesia. International Journal Of Islamic Khazanah, 10(1), 1-10.

Alfaqi, M. Z. (2015). Memahami Indonesia Melalui Prespektif Nasionalisme, Politik Identitas, Serta Solidaritas. Jurnal Pendidikan Pancasila Dan Kewarganegaraan, 28(2).

Andriyani, L. (2019). Politik Identitas Di Pemilu Serentak 2019. Jurnal Demokrasi, 4(1).

Anwar, S., \& El Fiah, R. (2018). Urgensi Pengembangan Kurikulum Pendidikan Islam Berwawasan Kebangsaan. Akademika: Jurnal Pemikiran Islam, 23(2), 435-454.

Aslichati, L. A. (2014). Metode Penelitian Sosial. Tangerang Selatan: Universitas Terbuka.

Aswin, M. (2013). Model Pola Hubungan Harmoniasi Antar Umat Beragama Di Kota Medan. Journal Analytica Islamica, 2(2), 292-303.

Dewi, E. (2012). Pemikiran Filosofi Ali Syari'ati. Substantia: Jurnal Ilmu-Ilmu Ushuluddin, 14(2), 232-2442.

Djuyandi, Y., \& Azmi, M. F. (2017). Fundamentalisme Islam Dalam Pilkada Dki Jakarta Tahun 2017. Jurnal Bawaslu, 3(2).

Haboddin, M. (2012). Menguatnya Politik Identitas Di Ranah Lokal. Journal of Government And Politics, 3(1), 109-126. Https://Doi.Org/10.18196/Jgp.2012.0007

Haboddin, M. (2017). Memahami Kekuasaan Politik. Universitas Brawijaya Press.

Hakiki, K. M. (2011). Politik Identitas Agama Lokal: Studi Kasus Aliran Kebatinan. Al-Adyan, Xi(1), 159-174.

Hasbullah, M. (2017). Islam \& Transformasi Masyarakat Nusantara. Prenada Media.

Kaelan, H. (2010). Metode Penelitian Agama Kualitatif Interdisipliner. Yogyakarta: Paradigma.

Karmida, R. (2018). Konstruksi Realita "Aksi Damai" Dalam Pemberitaan Gerakan Bernuansa Agama Di Metrotv. Jurnal Ilmu Komunikasi Akrab, 2(2). 
Madjid, N. (1997). Tradisi Islam: Peran Dan Fungsinya Dalam Pembangunan Di Indonesia. Jakarta: Paramadina.

Madjid, N. (2019). Islam: Doktrin \& Peradaban. Gramedia Pustaka Utama.

Madjid, N., \& Roem, M. (2007). Tidak Ada Negara Islam. Surat Menyurat Dengan Mohammad Roem, Paramadina.

Mufakat, M. G. M. (2012). Musyawarah Mufakat: Gagasan Dan Tradisi Genial Demokrasi Deliberatif Di Indonesia. Jurnal Politik Indonesia, 1(2), 21-30.

Muhamad, I. (2017). The Existence Of Urgency And Religious Culture In Achieving The Objective Of Education In Schools. Islam Transformatif: Journal Of Islamic Studies, 1(1), 56-62.

Noer, D. (1983). Ideologi, Politik Dan Pembangunan. Yayasan Perkhidmatan.

Nurcholish, M. (1997). Masyarakat Religius. Jakarta: Paramadina.

Pradipta, A. L., Hidayah, N. W. N., Haya, A. N. A., Ervani, C., \& Kristanto, D. (2018). Analisis Bingkai Pemberitaan Aksi Bela Islam 2 Desember 2016 (Aksi 212) Di Media Massa Bbc (Indonesia) \& Republika. Informasi, 48(1), 109-124.

Sari, E. (2016). Kebangkitan Politik Identitas Islam Pada Arena Pemilihan Gubernur Jakarta. Kritis: Jurnal Ilmu Sosial Dan Ilmu Politik Universitas Hasanuddin, 1(1), 145-156.

Sugiyar, S. (2018). Interaksi Masyarakat Multikultural Dalam Bingkai Keberagaman Agama. Kalam: Jurnal Agama Dan Sosial Humaniora, 6(1).

Sukmana, Y. (2019). Politik Identitas Berlebihan Mengubah Mimbar Keagamaan Jadi Panggung Politik.

Suyanta, S. (2018). Mencari Format Masyarakat Ideal. Jurnal Ilmiah Islam Futura, 7(2), 60-72.

Tanthowi, P. U. (2019). Muhammadiyah Dan Politik: Landasan Ideologi Bagi Artikulasi Konstruktif. Maarif Journal, 14(2), 93-113.

Ulfa, M. (2013). Mencermati Inklusivisme Agama Nurcholish Madjid. Kalimah, 11(2), 238. Https://Doi.Org/10.21111/Klm.V11i2.94

Wawancara. (2019a). Wawancara Dengan Mahfudz Amin.

Wawancara. (2019b). Wawancara Mendalam Dengan Ahmad Fitrian. 